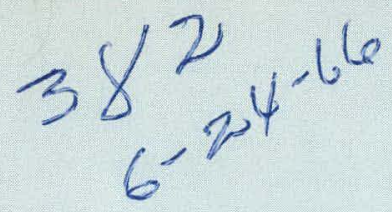

\title{
SINGLE-TRANSDUCER DIFFERENTIAL
} MEASURING DEVICE (U)

\section{G. Whitten}

RELEASED FOR ANNOUNCEMENT

IN NUCLEAR SCIENCE ABSTRACTS

\section{UNION CARBIDE CORPORATION}

\section{NUCLEAR DIVISION \\ OAK RIDGE Y-12 PLANT}

operated for the ATOMIC ENERGY COMMISSION under U. S. GOVERNMENT Contract W-7405 eng 26 


\section{DISCLAIMER}

This report was prepared as an account of work sponsored by an agency of the United States Government. Neither the United States Government nor any agency Thereof, nor any of their employees, makes any warranty, express or implied, or assumes any legal liability or responsibility for the accuracy, completeness, or usefulness of any information, apparatus, product, or process disclosed, or represents that its use would not infringe privately owned rights. Reference herein to any specific commercial product, process, or service by trade name, trademark, manufacturer, or otherwise does not necessarily constitute or imply its endorsement, recommendation, or favoring by the United States Government or any agency thereof. The views and opinions of authors expressed herein do not necessarily state or reflect those of the United States Government or any agency thereof. 


\section{DISCLAIMER}

Portions of this document may be illegible in electronic image products. Images are produced from the best available original document. 
Printed in USA. Price \$1.00. Available from the Clearinghouse for Federal Scientific and Technical Information, National Bureau of Standards,

U.S. Department of Commerce, Springfield, Virginia

\section{LEGAL NOTICE}

This report was prepared as an account of Government sponsored work. Neither the United States, nor the Commission, nor any person acting on behalf of the Commission:

A. Makes any warranty or representation, expressed or implied, with respect to the accuracy, completeness, or usefulness of the information contained in this report, or that the use of any information, apparatus, method, or process disclosed in this report may not infringe privately owned rights; or

B. Assumes any liabilities with respect to the use of, or for damages resulting from the use of any information, apparatus, method, or process disclosed in this report.

As used in the above, "person acting on behalf of the Commission" includes any employee or contractor of the Commission, or employee of such contractor, to the extent that such employee or contractor of the Commission, or employee of such contractor prepares, disseminates, or provides access to, any information pursuant to his employment or contract with the Commission, or his employment with such contractor. 
II. $\$ 1.00 ; \operatorname{MN} .50$

Date Issued: June 21, 1966

Report Number Y-1541

Instruments

TID -4500

\section{UNION CARBIDE CORPORATION Nuclear Division}

$$
\therefore Y-12 \text { PLANT }
$$

Contract $W$-7405-eng-26

With the US Atomic Energy Commission

\section{SINGLE-TRANSDUCER DIFFERENTIAL MEASURING DEVICE}

L. G. Whitten

RELEASED FOR ANNOUNCEMENT

IN NUCLEAR SCIENCE ABSTRACTS

Oak Ridge, Tennessee 
Report Number $\quad Y-1541$

Instruments

TID -4500

Distribution:

\begin{tabular}{|c|c|c|c|}
\hline Ackerson, R. D. & (AFSC) & & \\
\hline Bailey, E. W. & & Lewis, F. O. & (ORGDP) \\
\hline Ballenger, H. F. & (2) & McLendon, J. D. & \\
\hline Bell, B. B. & & Meeks, E. J. & (AFSC) \\
\hline Bernander, N.K. & & Mitchel, G. W. & \\
\hline Briscoe, O. W. & & Rader, D. H. & \\
\hline Burkhart, L. E. & & Stoner, H. H. & \\
\hline Center, C. E. & (ORGDP) & Trotter, T. C. & \\
\hline Christman, A. M. & & Waters, J. L. & \\
\hline Cowen, D. D. & (ORNL) & Whitson, W. K. & \\
\hline Evans, G. W. & & Whitten, L. G. & (15) \\
\hline Harwell, W. L. & $(\mathrm{ORGDP})(5)$ & Williams, J. L. & (5) \\
\hline Hemphill, L. F. & & Winkel, R. A. & (Paducah) \\
\hline Huber, A. P. & (ORGDP) & Yaggi, W. J. & \\
\hline Jackson, V.C. & & Zurcher, E. & \\
\hline Jennings, D. A. & & Y-12 Central Files & (160) \\
\hline Keller, C. A. & $(A E C-O R O)(4)$ & Y-12 Central Files & $(Y-12 R C)$ \\
\hline
\end{tabular}

In addition, this report is distributed in accordance with the category Instruments, as given in the "USAEC Standard Distribution Lists for Unclassified Scientific and Technical Reports", TID -4500 . 


\section{ABSTRACT}

A review of current practice showed that to keep abreast of present-day machine-tool capabilities, the precision of on-themachine gaging should be improved by at least an order of magnitude. A simple, easily operated, portable, on-themachine measuring device utilizing a single-transducer measuring system was designed, built, and tested. Its performance demonstrated an improvement in precision over current practice by one to two orders of magnitude. 
CONTENTS

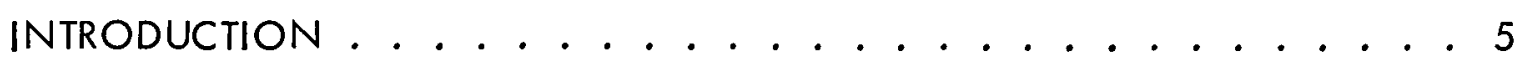

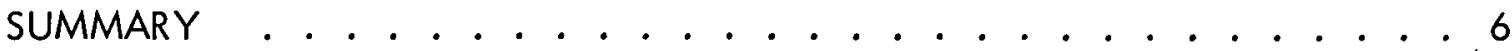

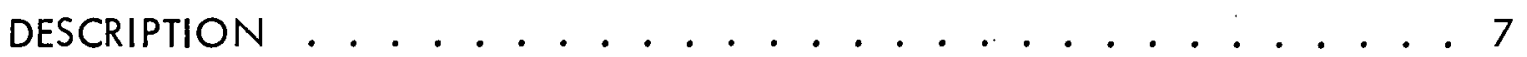




\section{INTRODUCTION}

The increasing use of tape-controlled machines has created a disparity between machining and measurement technology. While industry has been building machines to move more and more accurately and in smaller increments, practice in part measurement has failed to keep pace. Handheld inside-diameter and outsidediameter micrometers are simply no longer adequate to gage parts that are being produced on machineshaving twenty-five-microinch incremental movements or less.

A single-transducer differential measuring device was proposed that could be mastered with gage blocks, carried to the machine, and be used by hand to determine part size. A precision of better than the machine's least readout was the goal to be realized. Since machines with tool-path accuracy in the order of fifty microinches are commonplace today, it was deemed appropriate to aim at measuring part diameters with an accuracy of twenty-five microinches or better. 
A single-transducer differential measuring device has been built and tested for checking critical dimensions of a part while the part is still on the machine. 


\section{DESCRIPTION}

The normal arrangement for measuring diameters with gaging cartridges is to pick up one end of a diameter, rotate the stylus, move a measured amount, and then read the deviation at the other end. Alternatively, opposed matched gaging cartridges could be used with the gaging cartridge output being fed as input to matched amplifiers. The differential signal of the amplifiers would then either analog or digitally display the difference from the nominal dimension.

Both of these methods have disadvantages. In the first method, the traversing of a known distance requires a device such as a measuring machine and obviously is not portable and could not be used on the machine. The disadvantage of the second method is that two gage cartridges and two matched amplifiers are required to obtain the desired results.

Figure 1 shows schematically the single-transducer differential measuring device which was developed to perform all of the functions of the second method, while requiring only one cartridge and one amplifier. The device consists of two parallelreed "feeler" supports. Attached to one parallel-reed subassembly is a linear differential-transformer coil. Attached to the other parallel-reed subassembly is the armature for this coil. Movement of the coil feeler, the armature feeler, and/or both feelers, results in a proportional movement of the coil with respect to the core. This gives a differential measurement of the feeler displacement to a single amplifier.
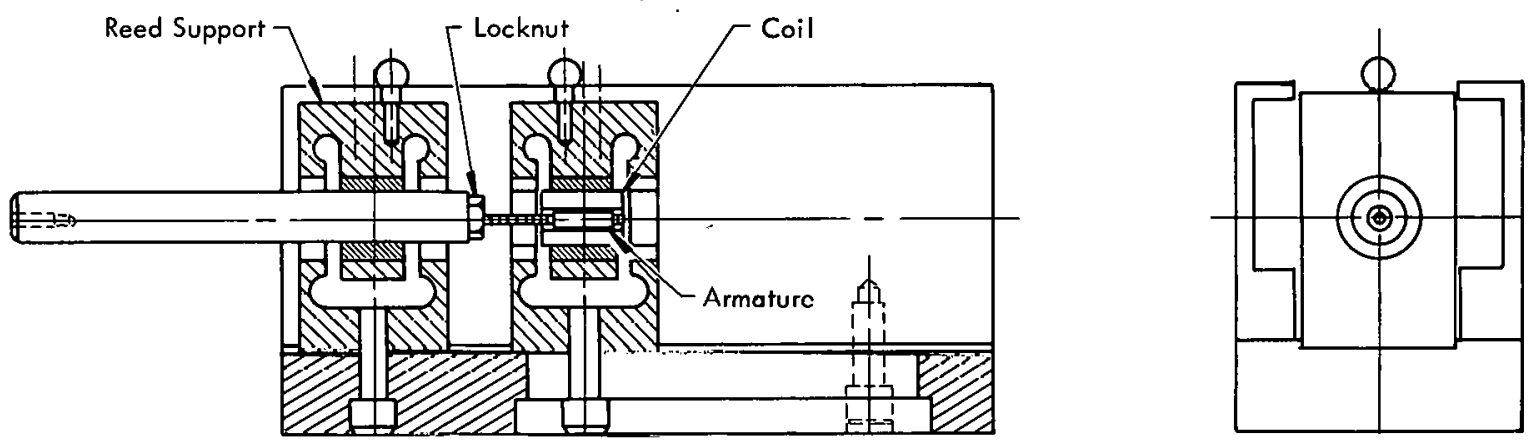

Figure 1. THE SINGLE-TRANSDUCER DIFFERENTIAL MEASURING DEVICE.

Later models of this device have made use of different probe assemblies such as precisely located balls for gaging a known distance down from the surface of the part. The device can be made either shorter or longer simply by decreasing or increasing the length of the frame and the corresponding transfer rod.

Another modification, shown in Figure 2, depicts an arrangement using a plain adjustable bar and a staindard eles:tronic gage cartridgc. 

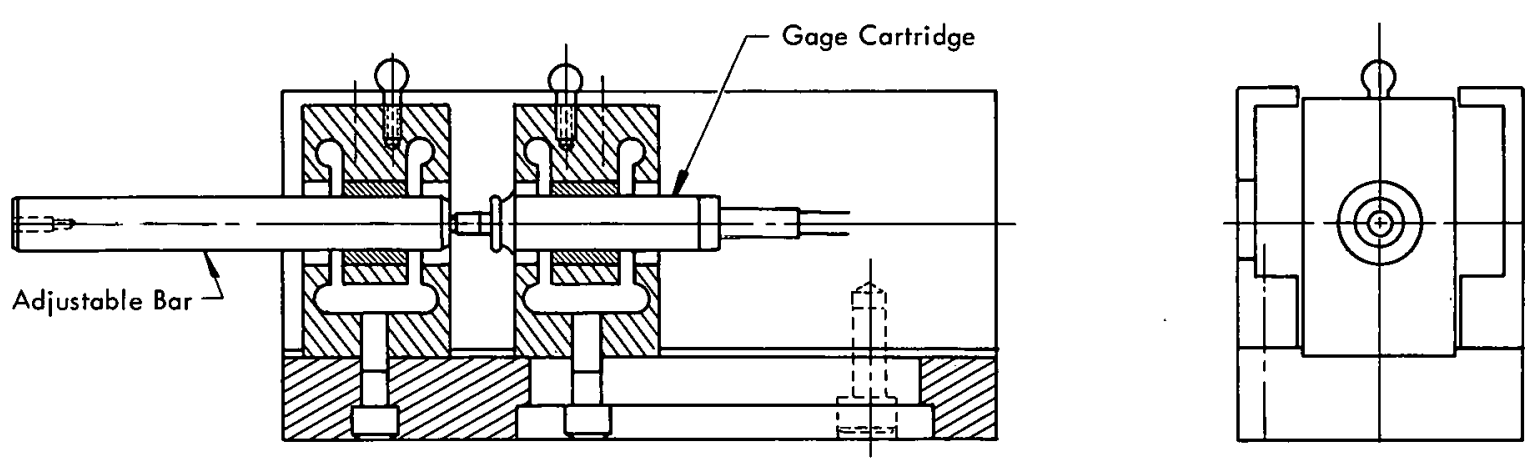

Figure 2. MODIFIEd SINGLE-TRANSDUCER DIFFERENTIAL MEASURING DEVICE.

Advantages of the parallel-reed arrangement are:

1. Hysteresis is kept to a minimum, thereby reducing zero shift.

2. There are no bearings to clog, stick, or cause friction.

3. Gaging pressure can be reduced to zero by the proper placement of the subassemblies.

This arrangement is adaptable to the measurement of outside diameters, inside diameters, length, and heights. Variations in the measurement of heights may be achieved by substituting: (1) the body of a mechanical indicator in the described core position and the mechanical actuating shaft of the indicator in the armature position; (2) capacitance plules at the core and armature positions; (3) strain gages or strain wire couples between the core and armature positions, and (4) optical interference equipment between the core and armature positions.

In addition to the dimensional measurements, the device is adaptable to the calibration of force (load cell), and to the measurement of strain, differential velocity and acceleration, and displacements.

The described device has been used successfully to measure parts produced on a tape-controlled turning machine. 